\title{
The bumpy road to a competitive economy - economic governance in the European Union
}

\author{
Magdalena Tusińska \\ University of Economics in Katowice \\ Poland \\ e-mail:magdalena.tusinska@ue.katowice.pl
}

\begin{abstract}
Over the last few years the European Union and its Member States have made a series of important decisions that imply stronger economic coordination in the EU as a whole, particularly for the euro area. The ineffectiveness of the pre-crisis governance based mainly on an open method of coordination was the trigger of these changes. The aim of this paper is to discuss a deepening of economic integration and of political coordination. The emphasis is put mostly on the matter of competitiveness. The novelty of this paper consists of linking the criticism of the "old economic governance" with recently implemented mechanisms. The elements of the new economic governance correct the weaknesses of the foregoing methods, yet bring forth other obstacles.

We can't solve problems by using the same kind of thinking we used when we created them Albert Einstein
\end{abstract}

Received: June, 2014

Keywords: macroeconomic policy coordination, European Union, Member States, economic governance, competitiveness

JEL Classification: E601, F 360, F550

\section{INTRODUCTION}

The renewal of the European development model and the redefined role of the European Union (EU) in the new post-crisis international order is guided by "Europe 2020 " as a successor to a decade-long experience of transnational coordination of economic and social policies framed by the Lisbon Strategy (LS). The formulation of the new Strategy took place in a context which is very different from that of the original Lisbon Agenda in 2000. The EU's interdependent economies are still reeling the impact of the financial and economic crises and their long-term consequences, including the situation of public finances and deteriorating labour markets. The focus of Europe's long-term challenges has also shifted. Global competition coming from emerging countries has added to the concern that the EU is falling behind the United States and Japan in terms of productivity growth and innovativeness.

The crisis was in fact a breakthrough inspiring a thorough assessment of the EU's experiences. One conclusion could be that the solution to coming challenges involves deepening economic integration and increased 
political coordination. It is believed, that stronger governance is needed to ensure progress and achieve contemporary goals. The response to such a demand is not only in the form of the aforementioned Strategy "Europe 2020", but also other in other mechanisms which have been introduced or at the very least proposed.

The topic of the economic governance is very broad, thus the area of consideration has to be narrowed down - the paper aims to contribute to the debate on the current governance of the EU's competitiveness. It critically assesses the results of implementing the LS and considers how the mechanisms of its successor, as well as of other new instruments, have been improved. It is not about the content of the documents, but rather a modification of some mechanisms in Europe in the discussed topic, which may shed new light on the current governance. This paper presents the results of research based on the review of economic literature as well as EU documents and reports.

The article is structured into six parts. Following the introduction, a concise overview of the key definitions is provided. This is followed by a short description of the EU's situation in terms of its competitiveness. The next part looks back on the governance of the LS, providing a short overview of the open method of coordination (OMC). It enables one to realise how considerable the scale of the current changes is. The subsequent part examines the new governance architecture for EU policy coordination after 2010. The new rules are presented not only as a description, but also, as a response to the criticism of the old governance. In the final part of the analysis there is a display of the main findings leading to the conclusion of the article.

\section{COMPETITIVENESS - THE NOTION AND WAYS OF GOVERNANCE}

The term "competitiveness" is a catchall phrase used nowadays in a variety of contexts. Among many existing criteria (Pietrucha \& Czech-Rogosz \&Tusińska, 2013; Tusińska, 2014), it can be interpreted in two ways, namely: price competitiveness and non-price competitiveness (which is more controversial). Some of the definitions for both types of competitiveness as well as their issues are presented in table 1:

Some authors writing about non-price competitiveness do so with regard to innovativeness claiming that the latter is a fundamental part of the foremost. It is difficult to deny, because implementing innovations usually brings higher productivity, though definitions of competitiveness based solely on innovativeness seem to be too narrow. The same imputation can be raised with regard to the definitions popular in the past which focused on the ability of an economy to sell products and services on international markets. Thus, the definitions presented in table 1. seem to be more suitable. Regardless of the slight differences between these definitions, an economy which is competitive in any of the ways mentioned above, gains more benefits from international cooperation. A more competitive economy is likely to sustain growth, additionally it ensures socio-economic welfare to its citizens. Thus, the term "competitive" always has a positive connotation and most countries are competitiveness-oriented - at least in their economic policies. In other words, an economy which is more likely to sustain growth seems to be more competitive.

Gaining, keeping and enhancing the competitiveness of any entity requires the ability to think strategically. Apparently, the formulation of programmes or mechanisms by various institutions is an expression of that particular way of thinking. A premise to elaborate on that approach is the confidence that individual efforts are not enough to ensure the economic success of an entire country or a group of countries - there is a serious demand for a vision which provokes collective actions. The vision can be embodied in a strategy utilized and designed to modernise a country (a group of countries) by introducing structural reforms to prepare its economy for new challenges. It can be identified with the procedure of setting long-term priorities for economic systems, modifications of goals adjusted to predictions and current changes, indicating the 
amount and type of resources crucial for the achievement of such goals, and then with the means by which such factors can be obtained and rationally allocated within the particular system (Gościński, 1992, p. 32).

Table 1

The definitions and features of price and non-price competitiveness

\begin{tabular}{|c|c|}
\hline Price competitiveness & Non-prices competitiveness \\
\hline $\begin{array}{l}\text { - measured with the nominal effective exchange rate } \\
\text { (NEER) or, more frequently, with the real effective } \\
\text { exchange rate (REER) (Pietrucha et. al, 2013, p. 30) } \\
\text { - the NEER ("trade-weighted currency index") tracks } \\
\text { changes in the value of a given country's currency } \\
\text { in relation to the currencies of its principal trading } \\
\text { partners; is calculated as a weighted average of } \\
\text { the bilateral exchange rates with those currencies } \\
\text { (Pietrucha et. al, 2013, pp. 31, 34); } \\
\text { - REER aims to assess a country's price or cost } \\
\text { competitiveness relative to its principal competitors } \\
\text { in international markets. It corresponds to the NEER } \\
\text { deflated by selected relative price or cost deflators } \\
\text { (Bossak, 2013, pp. 231-232, Pietrucha et. al, 2013, } \\
\text { pp. } 32,34 \text { ); } \\
\text { - more important on lower stages of development; } \\
\text { - the lack of such competitiveness is usually equal to } \\
\text { external imbalance interpreted as growing deficit in } \\
\text { a current account. }\end{array}$ & $\begin{array}{l}\text { - the capacity of companies, industries, regions, nations, and } \\
\text { supranational regions to generate, while being continuously } \\
\text { exposed to international competition, relatively high factor } \\
\text { income and factor employment levels on a sustainable basis } \\
\text { (Hatzichronologou, 1996, p. 3); } \\
\text { - more difficult to assess than price competitiveness, because } \\
\text { the impact is put on the potential/capability of an economy } \\
\text { which seems to be unmeasurable, though some organisa- } \\
\text { tions (like World Economic Forum - WEF, International } \\
\text { Institute for Management Development) construct rankings } \\
\text { of countries on the basis of aggregated indexes of competi- } \\
\text { tiveness. } \\
\text { - a set of institutions, policies, and factors that facilitate pro- } \\
\text { ductivity in a given country. The productivity determines } \\
\text { the level of prosperity that can be achieved as well as the } \\
\text { rates of return on investments. These, in turn, are the funda- } \\
\text { mental drivers of the economic growth rates (WEF, 2013, } \\
\text { p. 4); }\end{array}$ \\
\hline
\end{tabular}

Source: Own compilation

Considering such a programme for a group of national economies, like the EU consisting of 28 countries, the task becomes even more complicated, because "one size does not fit all". Another challenge is in how to enforce the implementation of the structural reforms among the countries. At some point, when some of the Member States (MS) had been falling behind in terms of their competitiveness, an apparent inability to deal with such problems was revealed. Some negative trends have been observed in both aspects of competitiveness, namely:

- The asymmetry of price competitiveness among euro zone countries - the years preceding the crisis were marked by striking external and internal macroeconomic imbalances. The loss of price competitiveness linked mainly with the growth of unit labour costs (ULC) resulted in growing current accounts deficits of euro zone peripheral countries (i.e. Greece, Ireland), whereas considerable surpluses could have been observed in the balances of payments (BOP) in the core economies, Germany being a good example (Pietrucha et. al, 2013).

- The asymmetry of non-price competitiveness among EU countries - as in previous years, the current year's top 10 (according to WEF) remain dominated by some European countries, with Finland, Germany, Sweden, the Netherlands, and the United Kingdom confirming their places among the most competitive economies. In contrast some European countries occupied very different positions, for example: Poland $-42 \mathrm{nd}$, Portugal $-51 \mathrm{st}$, Romania $-76 \mathrm{th}$, Slovakia -78 th, Greece -91 st; assessing the competitiveness landscape of 148 economies (WEF, 2013).

These asymmetries have had a negative impact on the condition of the EU as a whole and contributed to the scale and the consequences of the crisis which, using the words of J.M. Barroso, (...) has also exposed some fundamental truths about the challenges that the European economy faces. And in the meantime, the global 
economy is moving forward (European Commission, 2010b, p. 2). During the first decade of the current century the growing asymmetries were accompanied by the Lisbon Strategy.

\section{THE LISBON STRATEGY AT A CRITICAL GLANCE}

It seems to be ironic that a decade which started with such high hopes for Europe ended with the crisis a long way from the ambition declared in the LS to make the EU the most dynamic and competitive knowledgebased economy in the world capable of sustainable economic growth with more and better jobs and greater social cohesion, and respect for the environment by 2010 (Lisbon European Council, 2000). Only in 2004 did this over-ambitious priority turn out to be unrealistic, but what seems to be crucial given the topic of the article is that the weak economic governance contributed to such poor results through the implementation of the Lisbon reforms. It was stated: External events since 2000 have not helped in achieving the objectives but the EU and its Member States themselves have clearly contributed to slow progress by failing to act on much of the Lisbon Strategy with sufficient urgency. Such a disappointing delivery is due to an overloaded agenda, poor coordination and conflicting priorities. Still, a key issue has been the lack of determined political action (the High-Level Group, 2004, p. 6).

In the EU, a strategy is a top-down agenda consisting of general and operational objectives. It is part of a so-called "soft law framework" (Ryszkiewicz, 2013, pp. 75-76, 80), because the European strategies are implemented according to the OMC which was presented as an innovation designed to manage the implementation of a vast reforms package that could not be implemented merely through legislative means. The OMC was deployed as an instrument of governance that sets its voluntary nature and conviction as a counterweight to approaches of a compulsory legal nature. So was the LS, a multi-sectoral programme based on lax transnational cooperation as well as common and shared efforts. (Collignon et.al, 2005; European Parliament, 2010). The key components of the OMC are notably common objectives, commonly agreed EU indicators, EU monitoring, peer review, and evaluation of national strategies (Zeitlin 2010, pp. 253-273).

It is important to mention that the national strategies (National Reform Programmes - NRPs) were added only in the relaunched LS (in 2005 - after midterm review) as an element of the improved governance which was supposed to enhance freedom for the MS to set their own priorities. Additional elements of the modified governance were also a link to the cohesion policy of the EU and 24 Integrated Guidelines for Growth and Jobs (IGs) as a policy instrument aimed at development and implementation of the LS.

In spite of such changes, the LS has only brought limited results undermining Europe's credibility, and questioning its capacity to adapt its economic and social model to a more challenging world. The impression that the countries did not take ownership and "sell" the project at home was also unfortunate. The gap between the best performers and the laggards was arguably wider in 2010 than it had been in 2000. An example, Greece and Portugal were falling behind in terms of the reforms, whereas Germany and Scandinavian countries were forging ahead. It is impossible to conclude expressly how the reforms would have progressed in the absence of the Lisbon Agenda. However, it is hard to not think that most MS reform paths would not have been very different if the LS had never existed, because there has been no more policy convergence within the EU than there has been between the OECD countries. Thus, the LS may have had a modest influence on the reform process in some of the smaller economies, but in the larger ones, reforms have been driven by domestic political dynamics, not an external pressure (Tilford \& Whyte, 2010, p. 3). An additional factor was adopting 10 much poorer countries in 2004. In spite of the fact that those economies were catching up, an income per head in new Member States contributed to a diminishing average income throughout the EU as well as increasing the gap between the EU and the USA. 
The LS formally elapsed in June 2010 with the adoption of “Europe 2020" leaving the EU at a crossroads and in political agreement that they need to be equipped with a broader and more effective set of policy instruments to ensure future prosperity and standards of living.

\section{THE NEW GOVERNANCE OF COMPETITIVENESS}

"Europe 2020" puts forward three mutually reinforcing priorities (smart, sustainable, inclusive growth) and proposes headline measurable targets concerning employment, research and innovations, natural environment, education and reducing poverty (European Commission 2010b, p. 32). The topic of the competitiveness is interpreted very broadly. It concerns not only a matter of enhancing innovativeness, but also social issues are highlighted.

The Strategy brings together a common economic agenda and a stronger EU surveillance framework, which should be decided upon and monitored in a synchronised manner. A visual representation of the Strategy governance is given in Figure 1.
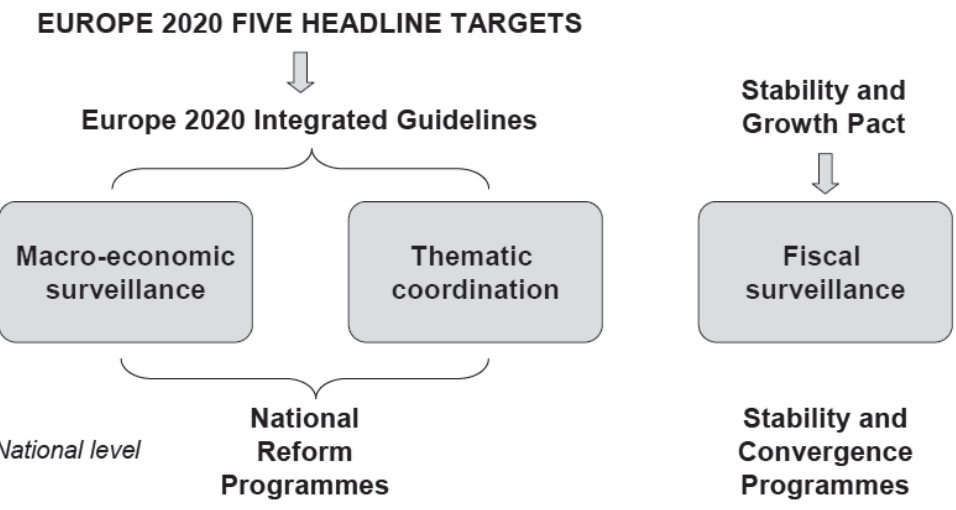

EU level

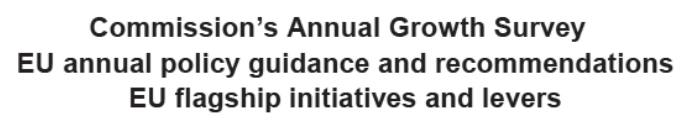

Fig. 1. Governance of the "Europe 2020" Strategy

Source: European Commission (2010c, p. 2).

The scheme presents the responsibilities of the Union and the national level, at the same time providing the general view on the new policy coordination and the main strands of the governance of the Strategy.

Overall, progress towards the "Europe 2020" targets is monitored as part of the European Semester (ES) in the EC's annual cycle to align fiscal, economic and structural policy coordination. It means that these topics are considered concomitantly. Within the framework of the ES, the Commission monitors the development along the dimensions of macroeconomic factors, public finances and growth-enhancing reforms, with the current strategy belonging to the latter (Ośrodek Informacji i Dokumentacji Europejskiej, 2013). 
The 5 EU headline targets and the 10 IGs serve as a policy framework for the production of NRPs. The 5 targets for the EU in 2020 are:

- $75 \%$ of the $20-64$ year-olds to be employed,

- 3\% of the EU's GDP (public and private combined) to be invested in R\&D/innovation,

- greenhouse gas emissions $20 \%$ (or even 30\%, if the conditions are right) lower than 1990 ,

$-20 \%$ of energy from renewables,

$-20 \%$ increase in energy efficiency,

- reducing school drop-out rates below $10 \%$,

- at least 40\% of 30-34-year-olds completing third level education,

- at least 20 million fewer people in or at risk of poverty and social exclusion.

This limited set of EU-level targets is translated into national targets in each EU country, reflecting different situations and circumstances (European Commission, 2010b).

The Stability and Growth Pact (SGP) is the framework for the establishment of Stability and Convergence Programmes (SCPs) that are the countries' plans for sound public finances and fiscal sustainability (for euro area countries, these are called Stability Programmes; for other MS - Convergence Programmes). The concrete priorities for a given year are detailed by the Commission in its Annual Growth Survey (AGS) by setting out more immediate actions for the coming months. In the European Semester the instruments of the SGP and the "Europe 2020" Strategy are aligned, while retaining their legal specificities (indicated in Fig. 1.). The new coordination should support competitiveness, as well as stable public finances.

In order to progress towards the "Europe 2020" goals, the Commission has come forward with a set of seven flagship initiatives covering: "A Digital Agenda for Europe", "Innovation Union", "Youth on the Move", "Resource Efficient Europe", "An Industrial Policy for a Globalisation era", "An Agenda for New Skills and Jobs", "European Platform Against Poverty" (European Commission, 2010b, p. 35). Among the levers there are: single market relaunch, trade and external policies and the EU financial support (European Commission, 2010c, p. 3).

The governance of the Strategy is based on three integrated strands: macro-economic surveillance, thematic coordination and fiscal surveillance under the SGP.

The first strand (Fig. 1.) is to ensure a stable macroeconomic environment conducive to growth and employment creation, taking account of spill-over effects across the Members. In accordance with the IGs, it will cover macroeconomic and structural policies to address macroeconomic imbalances, macrofinancial vulnerabilities, and competitiveness issues which have a macroeconomic dimension. Following a two-stage approach, the Commission has proposed a mechanism comprising a preventive arm and a corrective arm (European Commission, 2010a, pp. 3-4; European Commission, 2011).

The preventive arm with annual assessments of the macroeconomic imbalances risk includes an alert mechanism consisting of a scoreboard of external and internal indicators and alert thresholds, complemented by more qualitative analysis (the assessment of such indicators should be done by the Commission based on in-depth reviews, SCPs and NRPs). The scoreboard of external and internal indicators consists of ten measures with indicative thresholds. Half of them concern price competitiveness directly:

- 3-year backward moving average of the current account balance in percent of Gross Domestic Product (GDP), with a threshold of $+6 \%$ and $-4 \%$;

- net international investment position in percent of GDP, with a threshold of $-35 \%$;

- 5-year percentage change of export market shares measured in values, with a threshold of $-6 \%$;

- 3-year percentage change in nominal unit labour cost, with thresholds of $+9 \%$ for euro-area countries and $+12 \%$ for non-euro-area countries, respectively; 
- 3-year percentage change of the real effective exchange rates based on The Harmonised Index of Consumer Prices/Consumer Price Index deflators, relative to 35 other industrial countries, with thresholds of $-/+5 \%$ for euro-area countries and $-/+11 \%$ for non-euro-area countries, respectively (European Commission, 2012, p. 28).

The corrective arm, designed to enforce the implementation of remedies in case of harmful macroeconomic imbalances (if the EC considers that macroeconomic imbalances or the risk thereof exist, it will recommend that the Member State(s) concerned adopt a corrective plan with a clear roadmap of implementing measures and a deadline; for euro area countries, the enforcement mechanisms will include both fines and non-financial measures in case the imbalances are not corrected).

This mechanism is the central part of the enhanced (non-fiscal) macroeconomic country surveillance foreseen under "Europe 2020". It is assumed that, together with fiscal surveillance under the SGP, country surveillance aims at ensuring a stable macroeconomic environment conducive to growth and employment creation, taking into full account the interdependence of MS economies.

The second strand (Fig. 1.), thematic coordination, should be focused on growth-boosting reforms in the field of innovation and R\&D, resource-efficiency, business environment, employment, education and social inclusion (the elements of non-price competitiveness). The NRPs should set out Member States' proposed trajectories for meeting their agreed national targets deriving from the five headline targets and should track progress towards these targets. The IGs provide the measures which MS could consider to attain their targets and to tackle bottlenecks. Where appropriate, the countries should indicate how EU structural funds will be used in support of achieving the targets as well as the budgetary impact of these measures. NRPs should clearly focus on a limited set of priority measures, based on the principle that reforms must be sequenced. Progress will be monitored (in the cycle of ES) regarding five "Europe 2020" headline targets and the national targets which underpin them.

In parallel, fiscal surveillance under the Stability and Growth Pact as the third strand (Fig. 1.) will be enhanced to strengthen fiscal consolidation and foster sustainable public finances. It is assumed that stronger coordination between various areas in an economy has a positive impact on achieving goals connected with competitiveness and at the same time positively impacting other areas of concern.

Complimentary to the "Europe 2020" Strategy agenda and comprising of some additional reforms, the Euro+ Pact - has been agreed among euro area MS, as a reflection of their deeper interdependence, six non euro area countries have also chosen to sign up: Bulgaria, Denmark, Latvia, Lithuania, Poland and Romania (the remaining States are free to sign up if they wish). The Pact is embedded in the described economic governance framework and the commitments taken therein are included in the NRPs of the countries concerned. The Pact, agreed upon in March 2011, focuses on competitiveness, employment, sustainability of public finances and financial stability reinforcement. To foster price competitiveness, progress is assessed on the basis of wage and productivity developments and competitiveness adjustment needs. To assess whether wages are evolving in line with productivity, unit labour costs (ULC) are monitored over a period of time, by comparing them with developments in other Euro area countries and in the main comparable trading partners. For each country, ULCs are assessed for the economy as a whole and for each major sector (manufacturing; services; as well as tradable and non-tradable sectors). In order to support non-price competitiveness, measures to increase productivity are also proposed: further opening of sheltered sectors by measures taken at the national level to remove unjustified restrictions on professional services and the retail sector, specific efforts to improve education systems and promote R\&D, innovation and infrastructure, measures to improve the business environment, particularly for SMEs (European Council, 2011). 
Beyond the already functioning mechanisms, the topic of competitiveness in the context of the European deepening integration process and in governance reinforcement is raised also in other documents and in plans as well.

A solution to European challenges may be a true single market because it has the potential for raising growth. According to Michel Barnier, Member of the European Commission responsible for Internal Market and Services, the internal market is the best protection in times of crisis. Therefore the EU should implement the Single Market Act. A crucial aspect of the internal market is the services sector, which represents three-quarters of the EU gross domestic product. Unfortunately, the deadline for transposition of the services directive has already passed. If implemented properly, this legislation should open up the services market to true cross-border competition, bringing efficiency gains to a key sector of the European economy (M. Barnier, 2010).

Another proposition is a Convergence and Competitiveness Instrument - CCI. That would be a mutually agreed contractual arrangement and solidarity mechanism available for euro area MS who are under stress and require national structural reforms for competitiveness and growth but whose lack of implementation would have an adverse spill over effect on other MS of the euro area. The contracts are to be concluded between the individual eurozone countries and the EU. Their content is to be based on the Country Specific Recommendations from the European Semester. The EC argues that, as it was mentioned in the article, the crisis has shown that the necessary reforms have often been implemented too slowly or not at all in the Member States, and this has had a negative effect on other countries. The CCI now aims to take the European dimension into account in economic reforms and to enable the MS to implement the reforms more swiftly. Essentially, the reforms in question will increase competitiveness, largely by deregulating labour and product markets. The aim will also be to target public spending more competitively (European Commission, 2013).

\section{OLD FAILURES AND THE NEW ECONOMIC GOVERNANCE}

One may say that the new economic governance characterised in the foregoing section seems complicated. For example, some of the mechanisms pertain to the whole EU, whereas some of them involve solely the eurozone. Furthermore, there is a risk of generating bureaucracy and the growing costs involved. The fact of modifying the national priorities every year and growing elasticity also leads to questioning of the idea of long-term strategies. Moreover, some liberal economists criticise the social character of the current Strategy and warn of neglecting competitiveness (Bieńkowski, 2010, pp.166-172; Jasiński, 2010). Considering such doubts, at the stage of research assessing the new governance, it is worth reminding ourselves of the fact, that the new rules did not appear out of nowhere, but are a response to the criticism of the foregoing governance. In order to specify clearly how the new economic governance deals with old problems, the crucial issues are presented in the table 2.

Considering the arguments in table 2., it can be concluded that the EU acts according to the motto presented at the very beginning of the present article - there is an attempt to solve the existing problems by means of the new policy instruments, not with foregoing methods. It is expected that the new economic governance and the stronger policy coordination will support the competitiveness of the EU countries. 
Post-Lisbon Strategy critical reflection and the new competitiveness governance

\begin{tabular}{|c|c|c|}
\hline & The critical view & The features of the new economic governance \\
\hline 1 & 2 & 3 \\
\hline 1. & $\begin{array}{l}\text { - implementation of the SL as lax } \\
\text { coordination without a pilot (Col- } \\
\text { lignon et. al, 2005, Martens \& } \\
\text { Zuleeg 2010) }\end{array}$ & $\begin{array}{l}\text { - the clearer division of responsibilities between the EU and Member } \\
\text { States (European Commission 2010b); } \\
\text { - coordination of the process of reforms under the European Semester } \\
\text { (European Council, 2011); } \\
\text { - an implementation of variety of mechanisms, depending on the policy } \\
\text { area and the EU's competences, including "classic" OMC, strengthened } \\
\text { OMC with external review, fiscal policy mechanisms, funding and } \\
\text { legislative measures (Martens \& Zuleeg 2010, p. 10); }\end{array}$ \\
\hline 2. & $\begin{array}{l}\text { - lack of coordination most apparent } \\
\text { between the main economic objec- } \\
\text { tives and employment and social } \\
\text { policies (Fischer et. al 2010) }\end{array}$ & $\begin{array}{l}\text { - "Europe 2020" main priorities (smart, sustainable and inclusive growth) } \\
\text { are equally important (European Commission 2010b); } \\
\text { - coordination between the "Europe 2020" and Annual Growth Survey } \\
\text { (European Commission 2010c); } \\
\text { - a part of AGS is also the European Strategy of Employment (European } \\
\text { Commission, 2014); } \\
\text { - Euro+ Pact merging competitiveness, employment, sustainability of } \\
\text { public finances and financial stability reinforcement (Barroso, 2011); }\end{array}$ \\
\hline 3. & $\begin{array}{l}\text { - SL as a poorly-disguised attempt to } \\
\text { import "Anglo-Saxon neo-liberal- } \\
\text { ism" through the back door (Tilford } \\
\text { \& Whyte, 2010, p. 2, Fischer et. } \\
\text { al, 2010) }\end{array}$ & $\begin{array}{l}\text { - integration of social market economy approach and the idea of welfare } \\
\text { state (European Commission, 2010b); } \\
\text { - } \text { stronger focus on the social dimension in Europe, at all levels of gov- } \\
\text { ernment (European Commission, 2010b); }\end{array}$ \\
\hline 4. & $\begin{array}{l}\text { - lack of the necessary legal instru- } \\
\text { ments to make binding decisions } \\
\text { (Collignon et. al, 2005, p. 233) }\end{array}$ & $\begin{array}{l}\text { - reinforcing the role of EU institutions in providing political guidance } \\
\text { by the Lisbon Treaty: recommendations on other elements of macro- } \\
\text { economic surveillance are issued under article } 121 \text { of the Treaty, recom- } \\
\text { mendations on thematic issues are issued under articles } 121 \text { and } 148 \text { of } \\
\text { the Treaty; in cases where recommendations are not followed through } \\
\text { on sufficiently within the timeframe provided, the EC may issue policy } \\
\text { warnings and ensure effective enforcement through appropriate incen- } \\
\text { tives and sanctions (Lisbon Treaty); }\end{array}$ \\
\hline 5. & $\begin{array}{l}\text { - lack of specific focus of OMC, } \\
\text { - } \text { over broad intentions, imprecise } \\
\text { nature of the goals coined with EU- } \\
\text { wide generic statistical projections } \\
\text { (the High-Level Group, 2004) }\end{array}$ & $\begin{array}{l}\text { - five measurable EU targets for } 2020 \text { steering the process and translated } \\
\text { into national targets, introducing flagship initiatives (European Com- } \\
\text { mission } 2010 \mathrm{~b} \text { ); } \\
\text { - the number of IGs reduced from } 24 \text { to } 10 \text { in comparison to the LS (Eu- } \\
\text { ropean Commission } 2010 \mathrm{c} \text { ); }\end{array}$ \\
\hline 6. & $\begin{array}{l}\text { - unrealistic and non-evidence-based } \\
\text { strategy (the High-Level Group, } \\
\text { 2004); } \\
\text { - lack of linking policies to outcomes } \\
\text { (i.e. how to spell out what policies } \\
\text { will deliver the targets and how) } \\
\text { (Martens \& Zuleeg 2010, p. 10) }\end{array}$ & $\begin{array}{l}\text { - } \text { an average target for the EU based on country-specific targets for } \\
\text { each MS: overarching objective }=>\text { indicator (EU level) => priorities } \\
\text { (EU and/or national level) }=>\text { national target (European Commission, } \\
\text { 2010b); } \\
\text { - NRPs include a description of key measures to achieve the national } \\
\text { targets, including time-tables and budgetary impacts (European Com- } \\
\text { mission, 2010b); } \\
\text { - MS set out how they intend to tackle obstacles in achieving the objec- } \\
\text { tives with a focus on policy outcomes and demonstrating concrete } \\
\text { results (European Commission, 2010b); } \\
\text { - country-specific monitoring (European Commission, 2010b, 2010c, } \\
\text { Nowak-Far, 2012); }\end{array}$ \\
\hline 7. & $\begin{array}{l}\text { - disintegration of the responses to } \\
\text { medium- and long-term challenges } \\
\text { (European Commission, 2010b); }\end{array}$ & $\begin{array}{l}\text { - } 2020 \text { perspective but modifying the NRPs in the cycle of the ES (Euro- } \\
\text { pean Commission, 2010c); }\end{array}$ \\
\hline
\end{tabular}




\begin{tabular}{|c|c|c|}
\hline 1 & 2 & 3 \\
\hline 8. & $\begin{array}{l}\text { - weak ongoing monitoring and } \\
\text { progress evaluation (Collignon et. } \\
\text { al, 2005, Martens \& Zuleeg 2010) } \\
\end{array}$ & - the annual cycle of ES (Barroso, 2011, pp. 16-17); \\
\hline 9. & $\begin{array}{l}\text { - not elevating structural reforms to } \\
\text { the level of fiscal and monetary } \\
\text { policies (Martens \& Zuleeg } 2010 \\
\text { p. } 10 \text { ) }\end{array}$ & $\begin{array}{l}\text { - operationalising structural reform by integrating it into the EU's } \\
\text { decision-making process (through ECOFIN and the Eurogroup) and } \\
\text { linking it to the fiscal policy mechanisms, such as the SGP (Martens \& } \\
\text { Zuleeg 2010); }\end{array}$ \\
\hline 10. & $\begin{array}{l}\text { - lack of multi-level and multi-actor } \\
\text { implementation of the reforms } \\
\text { (Martens \& Zuleeg 2010, p. 10) }\end{array}$ & $\begin{array}{l}\text { - the tasks for the EU and the MS are more specified - so called "partner- } \\
\text { ship for progress" (European Commission, 2010b); } \\
\text { - the active role of MS in shaping the development of OMC processes } \\
\text { (Martens \& Zuleeg 2010); } \\
\text { - MS have direct responsibility for the policy initiatives to be undertaken } \\
\text { under the "Europe 2020" Strategy; their NRPs and the SCPs are the } \\
\text { cornerstones of their action (European Commission 2010c); }\end{array}$ \\
\hline 11. & $\begin{array}{l}\text { - lack of "pre-something" reaction } \\
\text { and preventions (Martens \& Zuleeg } \\
\text { 2010) }\end{array}$ & $\begin{array}{l}\text { - surveillance of macroeconomic imbalances (preventive arm) (Nowak- } \\
\text { Far, 2012, p. 56); } \\
\text { - stronger eligibility of Eurostat which is allowed to verify sent data } \\
\text { (Ministerstwo Finansów, p. 34); } \\
\text { - aligning the SGP and the "Europe 2020" brings a stronger ex-ante } \\
\text { dimension to economic coordination and surveillance in the EU (Euro- } \\
\text { pean Commision, 2010c). }\end{array}$ \\
\hline
\end{tabular}

Source: Author's elaboration.

It is difficult to state expressly whether due to the enhancement of OMC, as well as the new method of coordination the priorities will be achieved by 2020. In any case, the two main obstacles can be identified. Namely, the new programme seems to be overloaded, this may have a demotivating impact on the Member States, whereas the determination to be competitive at the national level is crucial. Furthermore, one of the postulates was to improve implementation mechanisms, but it seems that it has not been changed to a decent degree. The European Commission is allowed to apply pressure, but it concerns only Eurozone countries and their macroeconomic imbalances. When it comes to non-price competitiveness, the main way of reform mobilisations is still "peer pressure". An exception is CCI, but this solution is just a plan. Thus, the second obstacle might still be the lack of adequate tools to force MS to fulfil their commitments included in NRPs what can have a negative impact on the competitiveness of the entire EU.

\section{SUMMARY}

The Lisbon Strategy suffered from its lack of institutionalisation, because the OMC was built on the premise that the Member States could be trusted to evaluate themselves and motivate each other to achieve greater goals through coordination at MS level: in other words, they were left to their own devices, dooming the LS to failure. Consequently, the European countries were falling behind in the global competitiveness race and the Lisbon goals were not achieved. A good strategy should motivate all of those interested and included, which was impossible given the overambitious goal and "peer pressure" as a tool of control and motivation. Some modifications of the Agenda brought slight improvement, but the serious bump in the shape of the crisis on the way to the competitive economy proved, that the governance according to the renewed LS was not strong enough.

The debate on the "Europe 2020" Strategy that has succeeded the Lisbon Agenda took place under the shadow of the economic crisis, which will continue to shape economic policies and developments in Europe 
for the next decade and even beyond. It was believed, that a new strategy is needed, but that it has to be better implemented and rigorously monitored. Taking on board the lessons of the crisis and the deterioration of the competitiveness of the EU, the implementation of the "Europe 2020" Strategy is based on a much stronger policy framework. Through reinforced monitoring and guidance mechanisms, the EU level provides a supportive governance. As it was mentioned in the introduction, the EU's countries are still suffering from the impact of the crisis and its consequences. Thus, topics like public finances, deteriorating labour market or social exclusion have become an integral part of a debate about competitiveness.

Having weathered a painful recession, it is tempting to look ahead with a sense of cautious optimism, though, bearing in mind the foregoing experiences with the LS and the weaknesses of the new economic governance, the road to the competitive economy will probably not be unperturbed.

\section{REFERENCES}

Barnier, M. (2010), Acting without delay to clean up financial markets, Speech/10/27, Ecofin Council, Brussels, 16 February.

Barroso, J.M. (2009), Political Guidelines for the Next Commission, Brussels.

Barroso, J.M. (2011), Bilans paktu euro plus. Prezentacja na posiedzenie Rady Europejskiej 9.12.2011. Komisja Europejska.

Bieńkowski, W. (2010), Unia Europejska a dylematy nowych państw cztonkowskich - przypadek Polski, in: Wzrost gospodarczy czy bezpieczeństwo socjalne? W. Bieńkowski, M.-J. Radło (eds.) Wydawnictwo Naukowe PWN, Warszawa.

Bossak, J.W. (2013), Konkurencja i wspótpraca międzynarodowa, Difin, Warszawa 2013.

Collignon S., Dehousse R., Gabolde J., Jouen M., Pochet Ph., Salais R., Sprenger R.-U., Zsolt de Sousa H. (2005) The Lisbon strategy and the open method of co-ordination. 12 recommendations for an effective multi-level strategy, "Notre Europe Etudes \& Recherches", Policy paper n¹2, Notre Europe, March.

European Commission (2010a), Enhancing economic policy coordination for stability, growth and jobs - Tools for stronger EU economic governance. Communication from the Commission to the European Parliament, the European Council, the Council, the European Central Bank, the European Economic and Social Committee and the Committee of the Regions. Brussels, $\operatorname{COM}(2010) 367 / 2$.

European Commission (2012), European Economy. Scoreboard for surveillance of the macroeconomic imbalances, Occasional Papers 92, February.

European Commission (2010b), Europe 2020. A strategy for smart, sustainable and inclusive growth, Brussels, 3.3.2010 $\operatorname{COM}(2010) 2020$ final

European Commission (2010c), Governance, Tools and Policy Cycle of Europe 2020. http://ec.europa.eu/europe2020/pdf/ annex_swd_implementation_last_version_15-07-2010.pdf (18.05.2014).

European Commission (2014) http://ec.europa.eu/social/main.jsp?catId=81\&langId=pl (29.08.2014).

European Commission (2011), Scoreboard for the Surveillance of macroeconomic imbalances: envisaged initial design, Commission Staff Working Paper. Brussels, 8.11.2011 SEC(2011) 1361 final.

European Commission (2013), Towards a Deep and Genuine Economic and Monetary Union - The introduction of a Convergence and Competitiveness Instrument, $\operatorname{COM}(2013) 165$ final.

European Parliament (2010), The Lisbon Strategy 2000 - 2010 An analysis and evaluation of the methods used and results achieved. Final report, Directorate General for Internal Policies, Policy Department A: Economic and Scientific Policy Employment and Social Affairs. Brussels, July.

European Council (2011), The Euro Plus Pact. Stronger Economic Policy Coordination for Competitiveness and Convergence, Conclusions EUCO 10/1/11 REV 1, CO EUR 6, CONCL 3 Brussels, 20 April 2011. 
Facing the Challenge. The Lisbon strategy for growth and employment. Report from the High Level Group chaired by Wim Kok November 2004, Luxembourg: Office for Official Publications of the European Communities, 2004.

Fischer S., Gran S., Hacker B., Jakobi A.P., Petzold S., Pusch T., Steinberg Ph. (2010), „Europe 2020«-Proposals for the Post-Lisbon Strategy Progressive policy proposals for Europe's economic, social and environmental renewal, International Policy Analysis, Friedrich-Ebert-Stiftung, Berlin, May.

Gościński J., Sterowanie i planowanie: ujęcie systemowe, PWE, Warszawa 1992.

Hatzichronoglou T. (1996), Globalisation and Competitiveness Relevant Indicators, OECDScience, "Technology and Industry Working Papers", Paris OECD Publishing, Organisation for Economic Co-operation and Development $1996 / 05$.

Jasiński L.J. (2010), Uwagi na temat strategii „Europa 2020”, http://www.pte.pl/pliki/2/11/jasinski14.pdf (02.05.2014). Lisbon European Council, http://www.europarl.europa.eu/summits/lis1_en.htm (20.05.2014)

Martens H., Zuleeg F. (2010), Introduction. A new beginning: delivering sustainable well-being for Europe's citizens. in: Challenge Europe. Issue 20 Europe 2020: delivering well-being for future Europeans. A. Ahtonen, H. Bailey et. al. (eds.), European Policy Centre, March.

Ministerstwo Finansów. Biuro Pełnomocnika Rządu ds. Wprowadzenia Euro przez Rzeczpospolitą Polskę (2010), Kryzys grecki - geneza i konsekwencje. Dokument Uzupetniajacy do ram strategicznych narodowego planu wprowadzenia euro, Warszawa, 26 października $2010 \mathrm{r}$.

Lisbon Treaty, http://www.lisbon-treaty.org/wcm/the-lisbon-treaty.html (29.08.2014).

Nowak-Far A. (2012), Funkcjonowanie unii gospodarczej i walutowej, „Sprawy Międzynarodowe”, nr 1.

Ośrodek Informacji i Dokumentacji Europejskiej, Semestr europejski. Przewodnik po kluczowych dokumentach, Biblioteka Sejmowa, styczeń 2013.

Pietrucha J., Czech-Rogosz J., Tusińska M. (2013), Nierównowaga zewnętrzna krajów strefy euro, Wydawnictwo Uniwersytetu Ekonomicznego, Katowice.

Ryszkiewicz A. (2013), Od konwergencji do spójności i efektywności. Podstawy teoretyczne polityki spójności gospodarczej, spotecznej i terytorialnej Unii Europejskiej, Oficyna Wydawnicza SGH, Warszawa.

The Lisbon Strategy 2000-2010. An analysis and evaluation of the methods used and results achieved. Directorate General for Internal Policies. Policy Department: Economic and Scientific Policy Employment and Social Affairs. European Parliament, Brussels 2010.

Tilford S., Whyte P. (2010), The Lisbon Scorecard X: The Road to 2020, Centre for European Reform, London 2010.

Tusińska M. (2014), Konkurencyjność międzynarodowa a rozwój spoteczno-gospodarczy. Przypadek Polski na tle krajów Unii Europejskiej, Wydawnictwo Uniwersytetu Ekonomicznego w Katowicach, Katowice.

World Economic Forum (2013), The Global Competitiveness Report 2013-2014: Full Data Edition, Geneva 2013.

Zeitlin J. (2010), Towards a stronger OMC in a more social Europe 2020: A new governance architecture for EU policy coordination, in: Europe 2020: Towards a More Social EU? E. Marlier, D. Natali (eds.), Brussels: P.I.E. Peter Lang. 